\title{
Utilization of Tax Incentives, Tax Services and Existence of Tax Sanctions on Tax Compliance in Submitting SPT and Micro Business Sustainability at Kediri City during COVID-19 Pandemic
}

\author{
Amin Tohari', Andy Kurniawan², Basthoumi Muslih ${ }^{3}$, \\ Anneke Shierly Frycillia Widodo ${ }^{4}$, Leny Bima Saputra ${ }^{5}$ \\ 1,2,3,4,5 Faculty of Economic and Business, Universitas Nusantara PGRI Kediri, Indonesia
}

Corresponding Author: Amin Tohari

\begin{abstract}
This study aimed to analyze the utilization of tax incentives, tax sanctions, and tax services on tax compliance in submitting SPT and analyze them on micro business sustainability in Kediri City during Covid-19 pandemic. This study was a causality research design, using quantitative approach to examined the effects between exogenous and endogenous variables. The population were all micro business entrepreneurs in Kediri City with the sample size were 130 entrepreneurs. The analysis was used Structural Equation Modeling (SEM) analysis of SmartPLS program. The results showed that uutilization of tax incentives, tax service and the existence of tax sanctions had a positive and significant effect on tax compliance. Besides, tax service had a positive and significant effect on the business sustainability, but only tax incentives and tax sanctions had a positive and negligible effect on business sustainability. Kediri City needed to continue the existence of tax incentives, supervise on tax sanctions, improve tax services and motivate micro business entrepreneurs to submitting their SPT. So that, tax revenue of local government grows as expected. Meanwhile, to maintain micro business sustainability, local government with KPP Pratama Kediri has to guide and develop micro business entrepreneurs' knowledge about tax effects for their own benefits.
\end{abstract}

Keywords: business sustainability, tax compliance, tax incentive, tax sanctions, tax service

\section{INTRODUCTION}

Since affected by Covid-19 pandemic, Indonesia almost has experienced changes in all sectors. Likewise, the impact on state revenues from tax revenues has decreased significantly. Referring to Central Bureau of Statistics (BPS) data for 2021, sources of tax revenue before pandemic 2019 which was 1.9 trillion IDR, during pandemic 2020 was 1.69 trillion IDR and it raised up in 2021 by 1.74 trillion IDR [1]. Decreased state income from tax revenues during Covid-19 pandemic was possibly caused by income declining of micro business sector (UMKM) or Micro, Small Medium Enterprises (MSMEs). In addition, government policy to implementing social activity restrictions has reduced its profit. Recently, Indonesia has experienced an economic recession which means it has a deficit of income. If this economic condition is prolonged, will be a crisis, Small Medium Enterprises especially.

The low tax compliance is one of causing factors of this minimum Indonesia tax revenue. In a pandemic condition, low tax compliance in reporting Annual Tax Return (SPT) is possibly caused by diminished income or sales profit of micro 
businesses, especially in Kediri City. Even though, the better financial condition of MSMEs which is seen from obtained income, the higher tax compliance of taxpayers to fulfill their tax obligations [2].

As an effort to improve tax compliance, the government implemented tax incentives, aims to easing the tax burden of business entrepreneurs. Tax incentives are part of the National Economic Recovery (PEN) program and was one of the solutions in maintaining economic stability. One of the tax incentives that can be utilized by entrepreneurs is through PMK No. 86 of 2020. Empirically studied, tax incentives utilization has a positive effect on micro, small and medium enterprises (UMKM) at Tenun Troso Jepara [3]. Related to tax compliance, tax incentives caused by Covid19 has a positive and significant effect on tax compliance of taxpayers to reporting their Annual Tax Return (SPT) [4].

On the other side, the relevant tax agencies have encouraged efforts to increase tax payer compliance by enforcing tax sanctions against tax fraud perpetrators or taxpayers who does not carry out their tax obligations properly, intentionally or unintentionally. However, the low level of tax sanctions, especially administrative sanctions imposed on taxpayers, may be the reason why taxpayers are still late or did not submit their Annual Tax Return (SPT). Research results outlined, the existence of tax sanctions could increase awareness and compliance in the field of taxation and taxpayers can obey their obligations [5,6,7]. In addition, taxpayers who receive high tax sanctions will show higher compliance than those who receive low tax sanctions [8].

Tax compliance will also be achieved if the tax authorities treat taxpayers well, in this case it is considered as a form of good tax service. Taxpayers will respond positively to how tax authorities treat them. Particularly, the moral willingness of taxpayers to pay taxes or tax morale will increase when tax officials respect them, and then have an impact on people who feel satisfied and believe that the taxes collected are really used for public needs [9]. Some studies said that the tax services or tax authorities have an effect on MSME taxpayer compliance $[10,11]$. Emphasized by the statement that the higher service provided by tax officers, taxpayer compliance will increase [7].

As one of the provincial government units, Kediri is a city that has considerable potential in micro businesses to increase local tax revenues. However, Covid-19 pandemic has created its own paradigm among micro businesses in responding to the tax burden. With a study which discusses the government's efforts, hoped it can improve tax compliance and micro business sustainability in Kediri City. Thus, this study aims to analyze the utilization of tax incentives, tax sanctions and tax services on tax compliance in submitting SPT and micro business sustainability in Kediri City during Covid-19 pandemic.

\section{MATERIAL AND METHODS}

This research is designed to answer the problems that have been formulated and includes a causality research design, where the research design is prepared to examine the causal relationship between variables [12]. Quantitative approach used in this study, which was to examine the effects between exogenous variables and endogenous variables. Exogenous variables are the use of tax incentives, sanctions, and tax services, then endogenous variables are tax compliance and micro business sustainability. This study was conducted for micro business in Kediri City. Data was collected by distributing questionnaires consisting of 26 indicators of the Likert scale type with responses from 1 (strongly disagree) to 5 (strongly agree). Before distributing the questionnaires and collecting data, the instruments were distributed to pilot respondents and tested for validity and reliability.

The population in this study were all micro business entrepreneurs in Kediri City, while the sample were 130 entrepreneurs in Kediri City. This is based on the sample size 
that must be met in the modeling is to use a comparison of 5-10 observations for each estimated parameter (indicator) [13], meaning that the sample required is at least 5 times the number of indicators. This study has 26 indicators, so the research sample is determined as 5 × $26=130$ entrepreneurs.

The analysis used in testing the model and hypothesis is the Structural Equation Modeling (SEM) analysis of the SmartPLS program. The parameter estimation in SEM-PLS is obtained through three stages of the iteration process as follows. First stage: Determining estimated weight (Weight estimate) used to determine the score of the latent variable; Second stage: Determining path estimate that connects the latent variables and the estimated loading between the latent variables and their indicators; Third stage: Determining average estimate and the location of the parameters (regression constant values, intercepts) for indicators and latent variables [14]. Several studies using SEM-PLS have been conducted by previous researchers [15-17].

\section{RESULT}

Indicator's validity in forming latent variable was determined by looking at the convergent validity value of indicators in the model during evaluation of measurement model (outer model) through loading factor. If there were any indicators in the model that does not meet criterion for convergent validity (an absolute loading factor of $>0.7$ ), removed from the model. Convergent validity yields as follows:

Table 1. Result of Convergent Validity

\begin{tabular}{|c|c|c|c|c|c|}
\hline & Business Sustainability & Tax Compliance & Tax Incentives & Tax Sanctions & Tax Service \\
\hline x1.1 & & & 0.826 & & \\
\hline $\mathrm{x1.2}$ & & & 0.848 & & \\
\hline $\mathbf{x 1 . 3}$ & & & 0.917 & & \\
\hline $\mathrm{x1.4}$ & & & 0.896 & & \\
\hline $\mathrm{x} 2.1$ & & & & & 0.720 \\
\hline $\mathrm{x} 2.2$ & & & & & 0.712 \\
\hline x2.3 & & & & & 0.729 \\
\hline x2.4 & & & & & 0.745 \\
\hline $\mathrm{x} 2.5$ & & & & & 0.774 \\
\hline x2.6 & & & & & 0.735 \\
\hline $\mathbf{x 2 . 7}$ & & & & & 0.772 \\
\hline $\mathrm{x} 3.1$ & & & & 0.821 & \\
\hline $\mathrm{x} 3.2$ & & & & 0.786 & \\
\hline x3.3 & & & & 0.731 & \\
\hline $\mathrm{x} 3.4$ & & & & 0.845 & \\
\hline $\mathrm{x} 3.5$ & & & & 0.853 & \\
\hline y1.1 & & 0.717 & & & \\
\hline y1.2 & & 0.722 & & & \\
\hline y1.3 & & 0.733 & & & \\
\hline y1.4 & & 0.768 & & & \\
\hline y1.5 & & 0.728 & & & \\
\hline y2.1 & 0.754 & & & & \\
\hline y2.2 & 0.755 & & & & \\
\hline y2.3 & 0.765 & & & & \\
\hline y2.4 & 0.713 & & & & \\
\hline y2.5 & 0.724 & & & & \\
\hline
\end{tabular}

According to table 1, all indicators have an outer loading larger than 0.700 , hence no indicators should be removed from the model. The Average Variance Extracted (AVE) and composite reliability also could be used to evaluate the measurement model (outer model). The Average Variance Extracted (AVE) and composite reliability results are shown below:
Table 2. Result of Average Variance Extracted

\begin{tabular}{|l|l|l|}
\hline & $\begin{array}{l}\text { Composite } \\
\text { Reliability }\end{array}$ & $\begin{array}{l}\text { Average Variance } \\
\text { Extracted (AVE) }\end{array}$ \\
\hline Business Sustainability & $\mathbf{0 . 8 6 0}$ & 0.551 \\
\hline Tax Compliance & $\mathbf{0 . 8 5 4}$ & $\mathbf{0 . 5 3 8}$ \\
\hline Tax Incentives & $\mathbf{0 . 9 2 7}$ & $\mathbf{0 . 7 6 1}$ \\
\hline Tax Sanctions & $\mathbf{0 . 9 0 4}$ & $\mathbf{0 . 6 5 4}$ \\
\hline Tax Service & 0.895 & $\mathbf{0 . 5 5 0}$ \\
\hline \multicolumn{3}{|c|}{ Source: PLS Output }
\end{tabular}

The findings of Average Variance Extracted (AVE) and composite 
Amin Tohari et.al. Utilization of tax incentives, tax services and existence of tax sanctions on tax compliance in submitting SPT and micro business sustainability at Kediri city during COVID-19 pandemic.

dependability value can be seen in table 2 . The suggested AVE value should be larger than 0.5, and the AVE results from this study are known larger than 0.5 , implying that the indicator can explain more than half of the variance. Composite reliability was used to assess the consistency or reliability of latent or construct variables. If the composite reliability score was larger than
0.7 , latent variable is considered to be reliable. According to table 2, all of the study's latent variables had a composite reliability value larger than 0.7 .

\section{Result of the Model}

Partial least square model for tax compliance and business Sustainability used in this study is as follows:

Table 3. Partial least square tax compliance and business Sustainability model's estimation results

\begin{tabular}{|l|l|l|l|l|}
\hline & $\begin{array}{l}\text { Original Sample } \\
(\mathbf{O})\end{array}$ & $\begin{array}{l}\text { Standard Deviation } \\
(\text { STDEV) }\end{array}$ & $\begin{array}{l}\text { T } \\
(\mid \mathbf{O} / \text { STDEV })\end{array}$ & $\begin{array}{l}\text { Statistics } \\
\text { Palues }\end{array}$ \\
\hline Tax Incentives -> Business Sustainability & 0.130 & 0.122 & 1.061 \\
\hline Tax Incentives -> Tax Compliance & 0.412 & 0.085 & 4.833 \\
\hline Tax Sanctions -> Business Sustainability & 0.126 & 0.125 & 1.003 \\
\hline Tax Sanctions -> Tax Compliance & 0.324 & 0.107 & 3.036 \\
\hline Tax Service -> Business Sustainability & 0.587 & 0.086 & 6.819 \\
\hline Tax Service -> Tax Compliance & $0.198 \quad 0.082$ & $\mathbf{0 . 0 0 0}$ \\
\hline
\end{tabular}

This study's causation result can also be seen in the figure below:

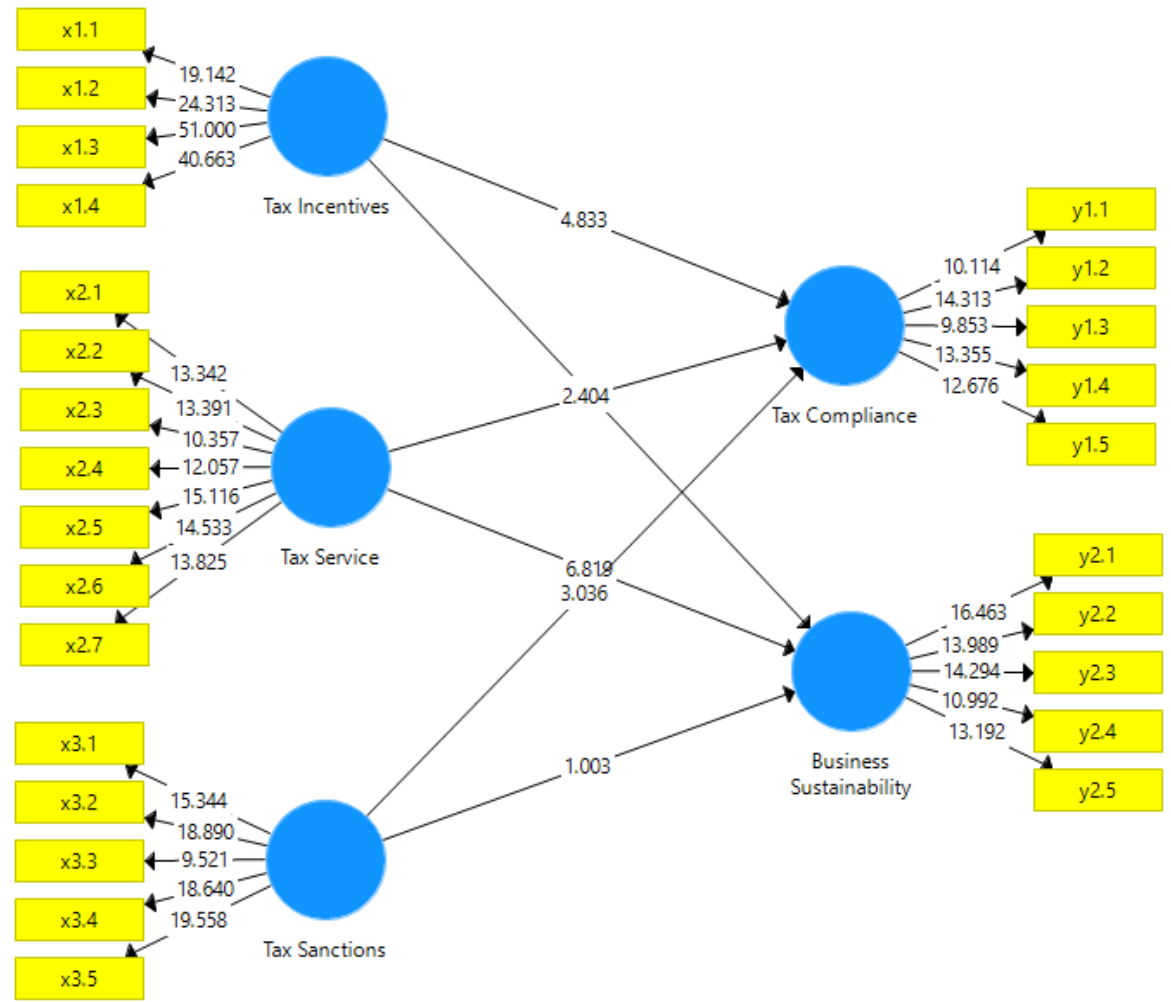

Figure 1. Model of tax compliance and business Sustainability

The results estimation of research model are:

$$
\begin{aligned}
& y_{1}=0.412 x_{1}+0.198 x_{2}+0.324 x_{2}, \text { and } \\
& y_{2}=0.130 x_{1}+0.587 x_{2}+0.126 x_{2}
\end{aligned}
$$

It can be observed from the structural equation that:

1. Latent variables of tax incentives had positive and significant effect on latent variables of tax compliance, with path coefficient 0.412 and p-value 0.000 . Thus, means that the higher tax incentives, the higher tax compliance.

2. Latent variable of tax service had positive and significant effect on latent variable of tax compliance, with path coefficient 0.198 and p-value 0.017 . 
Thus means that if tax service rises, the tax compliance rises as well.

3. Latent variables of tax sanctions had a positive and significant effect on latent variable of tax compliance, with path coefficient 0.324 and ap-value 0.003 . As a result, the higher tax sanctions, the higher tax compliance.

4. Latent variables of tax incentives had a positive and negligible effect on latent variable of business sustainability, with path coefficient 0.130 and p-value 0.289. Thus means that if tax incentives increases, business sustainability increases slightly, but not significantly.

5. Latent variables of tax service had a positive and significant effect on the latent variables of business sustainability, with a path coefficient 0.587 and p-value 0.000 . Thus indicates that if tax service rises, so business sustainability rises as well.

6. Latent variables of tax sanctions had a positive and negligible effect on the latent variable of business sustainability, with path coefficient 0.126 and p-value 0.316 . Thus means that if tax incentives rises, so does business sustainability rises as well, but only marginally.

\section{DISCUSSION}

As a developing City at East Java Province, Kediri has many potential businesses, especially for micro business. During Covid-19 pandemic, the local government has a lot of "homework" to maintain the stability of its economic conditions; such as paying attention on tax compliance of micro business entrepreneurs and maintaining their businesses sustainability.

According to results of this study, the higher tax incentives, the higher tax compliance. It means, if every entrepreneur at Kediri utilized tax incentives which are given by government, tax compliance will increase higher than ever. This results in line with other study which says tax incentives caused by Covid-19 has a positive and significant effect on tax compliance of taxpayers to reporting their Annual Tax Return (SPT) [4]. Otherwise, tax incentives had a positive and negligible effect on business sustainability. The result means, tax incentives not too effective determining business sustainability during Covid-19 pandemic. Even so, only positive result side of tax incentives utilization effect in line with micro, small and medium enterprises (UMKM) sustainability [3].

The result indicated if tax service rises, the tax compliance rises as well. It can be explained as respect as tax agency officers to taxpayers and more complete the tax services, they will more obey and fulfill their obligation which is reporting annual tax return (SPT). Consistently with other studies which are interpreted that the tax services or tax authorities have an effect on MSME taxpayer compliance [10,11], even the higher service provided by tax officers, taxpayer compliance will increase [7]. Likewisely, if the tax service related to business sustainability.

Still, third result shown that the existence of tax sanctions has a strong impact to tax compliance. Thus, the effect of tax sanctions on taxpayers also plays a role in determining compliance. This result was relevant to earlier findings which are interpret that the existence of tax sanctions could increase awareness and compliance in the field of taxation and taxpayers can obey their obligations [5,6,7]. But, the tax sanctions can not give impact so much to business sustainability. The possible reason for this condition is the government policy presence about tax relief during Covid-19 pandemic. Which means that the reporting or submitting annual tax return (SPT) for taxpayers could be postponed till end of year, so that the taxpayers have no mandatory reporting their SPT earlier.

\section{CONCLUSION}

Utilization of tax incentives, tax service and the existence of tax sanctions had a positive and significant effect on tax compliance. Besides, tax service had a positive and significant effect on the 
business sustainability, otherwise only tax incentives and tax sanctions had a positive and negligible effect on business sustainability.

Suggested for local government of Kediri City, need to continue the existence of tax incentives, supervise on tax sanctions, improve tax services (ex: providing digital services as e-services etc) and motivate micro business entrepreneurs to report or submit their SPT. So that, tax revenue of local government grows as expected. Meanwhile, to maintain micro business sustainability, local government with KPP Pratama Kediri has to guide and develop micro business entrepreneurs' knowledge about tax effects for their own benefits.

\section{Acknowledgement: None}

\section{Conflict of Interest: None}

\section{Source of Funding: None}

\section{REFERENCES}

1. BPS. Realisasi Pendapatan Negara. Online: Badan Pusat Statistik; 2021. Available from https://www.bps.go.id/indicator/13/1070/1/ realisasi-pendapatan-negara.html.

2. Budiman, N. A. Kepatuhan Pajak UMKM Di Kabupaten Kudus. Jurnal Profita. 2018; 11(2).

https://doi.org/10.22441/profita.2018.v11.02 .005 .

3. Indaryani, M., Budiman, N.A., Mulyani, S. Dampak Covid-19 dan Pemanfaatan Insentif Pajak terhadap Keberlangsungan Usaha pada UMKM Tenun Troso Jepara. Jurnal Manajemen dan Keuangan. 2020; 9(3): 276285.

https://ejurnalunsam.id/index.php/jmk/articl e/download/3035/2166/.

4. Alfina, Z., Diana, N. Pengaruh Insentif Perpajakan Akibat Covid-19, Pemahaman Perpajakan, Kesadaran Wajib Pajak Terhadap Kepatuhan Wajib Pajak dalam Menyampaikan Surat Pemberitahuan Tahunan (Studi Pada Wajib Pajak yang Terdaftar di KPP Pratama Malang Utara). Jurnal Ilmiah Riset Akuntansi: E-JRA. 2021; 10(4): 47-57. http://riset.unisma.ac.id/index.php/jra/article /view/10556.

5. Dewi, S., Widyasari, Nataherwin. Pengaruh Insentif Pajak, Tarif Pajak, Sanksi Pajak dan Pelayanan Pajak Terhadap Kepatuhan Wajib Pajak Selama Masa Pandemi Covid-19. Jurnal Ekonomika dan Manajemen. 2020; 9(2): 108-124. https://journal.budiluhur.ac.id/index.php/em a/article/view/1248.

6. Hendrawati, E., Pramudianti, M., Abidin, K. Pengetahuan Pajak, Sanksi Pajak, Modernisasi Sistem, Kondisi Keuangan Terhadap Kepatuhan Wajib Pajak UMKM Selama Pandemi Covid-19. Fair Value: Jurnal Ilmiah Akuntansi dan Keuangan. 2021; 4(1): 214-230. https://journal.ikopin.ac.id/index.php/fairval ue/article/view/516.

7. Antika, F.N., Mulyani, S., Budiman, N.A. Determinan Kepatuhan Wajib Pajak UMKM di Kabupaten Kudus. Jurnal Kajian Akuntansi dan Auditing (JKAA). 2021; 16(1): $15-28$. https://doi.org/10.37301/jkaa.v16i1.32.

8. Riasning, N.P, Amlayasa, A.A.B., Datrini, L.K. The effect of repeat tax amnesty and tax penalty policy on taxpayer compliance (an experimental study). International Journal of Research and Review. 2021; 8(10): 105-116. https://doi.org/10.52403/ijrr.20211015.

9. Rahayu, S.K. Perpajakan (Konsep dan Aspek Formal). Bandung: Rekayasa Sains; 2017.

10. Andrew, R., Sari, D.P. Insentif PMK 86/2020 Di Tengah Pandemi Covid 19: Apakah Mempengaruhi Kepatuhan Wajib Pajak UMKM Di Surabaya?. Jurnal Akuntansi dan Pajak. 2021; 21(2), 349-366. https://www.jurnal.stieaas.ac.id/index.php/jap/article/view/1597.

11. Salsabila, P.A., Junaid, A., Nurfadila. Faktor-Faktor yang Memengaruhi Kepatuhan Wajib Pajak Pada Masa Pandemi (Studi Kasus UMKM Kabupaten Soppeng). CESJ: Center Of Economic Students Journal. 2021; 4(2). http://jurnal.fe.umi.ac.id/index.php/CESJ/art icle/view/973.

12. Sanusi, A. Metode Penelitian Bisnis. Jakarta: Salemba Empat; 2011.

13. Ferdinand, A. Metode Penelitian Manajemen. Edisi 5. Semarang: Badan Penerbit Universitas Diponegoro; 2014. 
Amin Tohari et.al. Utilization of tax incentives, tax services and existence of tax sanctions on tax compliance in submitting SPT and micro business sustainability at Kediri city during COVID-19 pandemic.

14. Esteves, J., Casanovas, J., Collado, J.A.P. Modeling with Partial Least Squares Critical Success Factor Interrelationships in ERP Implementations. In: 9th Americas Conference on Information Systems; 2003 August 4-6; Tampa, FL, USA.

15. Tohari, A., Faisol. The Use Of Partial Least Squares Modeling In Finance Business Partnering Research. Jurnal Ilmiah Kursor. 2021; 11(1)

16. Linawati, Tohari, A. Permodelan Pertumbuhan Ekonomi Di Jawa Timur Melalui Fenomena Flypaper Effect. JURNAL EKUIVALENSI. 2021; 7(1):1-7.
17. Tohari, A. Pemodelan Derajat Kesehatan Menggunakan Structural Equation Modeling di Kabupaten Kediri. Jurnal Ilmiah Teori dan Aplikasi Statistika. 2018; 10(2):1-6

How to cite this article: Tohari A, Kurniawan A, Muslih B et.al. Utilization of tax incentives, tax services and existence of tax sanctions on tax compliance in submitting SPT and micro business sustainability at Kediri city during COVID-19 pandemic. International Journal of Research and Review. 2021; 8(11): 463-469. DOI: https://doi.org/10.52403/ijrr.20211158 